\title{
Distribution of free-living and particle-attached aerobic anoxygenic phototrophic bacteria in marine environments
}

\author{
Raphaël Lami ${ }^{1,2,7, *}$, Zuzana Čuperová3,4, Josephine Ras ${ }^{5,6}$, Philippe Lebaron ${ }^{1,2}$, \\ Michal Koblížek ${ }^{3,4}$
}

\author{
${ }^{1}$ UPMC Univ Paris 06, UMR 7621, LOBB, Observatoire Océanologique, 66651 Banyuls-sur-Mer, France \\ ${ }^{2}$ CNRS, UMR 7621, LOBB, Observatoire Océanologique, 66651 Banyuls-sur-Mer, France \\ ${ }^{3}$ Institute of Physical Biology, University of South Bohemia, Zámek 136, 37333 Nové Hrady, Czech Republic \\ ${ }^{4}$ Institute of Microbiology CAS, Opatovický mlýn, 37981 Třeboň, Czech Republic
}

${ }^{5}$ UPMC Univ Paris 06, UMR 7093, Lab. d'Océanographie de Villefranche-sur-Mer, 06230 Villefranche-sur-Mer, France ${ }^{6}$ CNRS, UMR 7093, LOV, 06230 Villefranche-sur-Mer, France

${ }^{7}$ Present address: College of Marine and Earth Studies, University of Delaware, Lewes, Delaware 19958, USA

\begin{abstract}
Aerobic anoxygenic phototrophic (AAP) bacteria are bacteriochlorophyll a-containing prokaryotes which can use both light and organic compounds as energy sources. This functional group is ubiquitous in the euphotic zone of the oceans. Nevertheless, life strategies, distribution patterns and physiology of AAP bacteria remain largely unknown. We combined infrared fluorometry, microscopic counts and HPLC pigment analysis to characterize free-living and particle-attached AAP bacterial populations. Using a size-fractionation approach, we found that the size distribution of AAP bacteria and the fraction of particle-attached cells varied greatly among different marine environments. In the open sea environments (Atlantic Ocean, offshore Mediterranean Sea), the main portion of AAP bacterial fluorescence was in the $<0.8 \mu \mathrm{m}$ fraction, which indicates that the majority of AAP bacteria in these regions were free-living cells $<0.8 \mu \mathrm{m}$. In these environments, only a few particleattached AAP bacteria were found. In coastal Mediterranean waters, the fraction of larger cells increased together with a few particle-attached cells, but $>50 \%$ of AAP bacteria were free living. In a coastal lagoon and in the deep chlorophyll a maximum at an offshore Mediterranean station, particle-attached AAP bacteria formed up to half of the AAP bacterial community. The results presented here suggest that AAP bacteria can take on either free-living or particle-attached lifestyles depending on environmental conditions.
\end{abstract}

KEY WORDS: AAP bacteria $\cdot$ Photoheterotrophy $\cdot$ Free-living bacteria $\cdot$ Particle-attached bacteria Resale or republication not permitted without written consent of the publisher

\section{INTRODUCTION}

Recent studies have revealed that a large fraction of marine prokaryotes are not strictly heterotrophic or autotrophic, but adopt a variety of mixotrophic strategies (Béjà et al. 2000, Kolber et al. 2000, Zubkov \& Tarran 2005). One group of these organisms, aerobic anoxygenic phototrophic (AAP) bacteria, performs photo- heterotrophic metabolism. They require organic substrates for their metabolism and growth and they are able to supplement a fraction of their energy demands using light (Yurkov \& Beatty 1998). AAP bacteria contain bacterial photosynthetic reaction centers with bacteriochlorophyll a (Bchl a) as the main light-harvesting pigment. The abundance of AAP bacteria varies greatly among different marine environments (Kolber 
et al. 2001, Cottrell et al. 2006, Mašín et al. 2006, Lami et al. 2007), but on average these bacteria account for about 2 to $4 \%$ of the total prokaryotes (Jiao et al. 2007).

Little is known about the distribution and physiology of marine AAP bacteria. Originally it was suggested that they would be abundant in oligotrophic environments, where the capacity to use light might represent a significant ecological advantage (Kolber et al. 2001). Later, AAP bacteria were also found in the highly eutrophic Baltic Sea (Koblížek et al. 2005), as well as in many freshwater environments (Mašín et al. 2008), which suggests that different AAP bacterial species can inhabit various environments and that their distribution is not determined solely by trophic status. Other factors such as light, temperature and nitrate availability were identified as potentially important factors controlling the abundance of AAP bacteria (Kolber et al. 2001, Mašín et al. 2006, Waidner \& Kirchman 2007).

In the pioneering study by Kolber et al. (2000), the authors suggested that the majority of the AAP bacterial population in the tropical Pacific is composed of free-living cells $<0.8 \mu \mathrm{m}$. In contrast, Allgaier et al. (2003) concluded that dinoflagellates could represent an 'important ecological niche' for AAP bacteria and speculated that these prokaryotes are directly attached to dinoflagellate cells. In addition, large fractions of particle-attached AAP bacteria were found in the Delaware estuary (Waidner \& Kirchman 2007). Furthermore, analyses of the metagenomic data sets from the Global Ocean Sampling expedition indicated a significant fraction of particle-attached AAP bacteria in the open ocean (Yutin et al. 2007). These conflicting results raise the question of whether these microorganisms in the natural environment are mostly free-living or particle-attached, and how this changes under different conditions. To address these questions, we used size fractionation to examine free-living and particleattached AAP bacteria in several contrasting marine environments.

\section{MATERIALS AND METHODS}

Sample collection. Three Mediterranean sites (SOLA, POLA and MOLA) in the Gulf of Lion were repeatedly sampled in spring and early summer 2007 (Table 1). The observatory Stn SOLA is in the Bay of Banyuls-sur-Mer, Stn POLA is on the continental shelf (7.4 km offshore), and the offshore Stn MOLA is on the continental slope ( $37 \mathrm{~km}$ from the coast). Nine stations in the North Atlantic Ocean were sampled in April 2008 during the OC443 cruise aboard the RV 'Oceanus'. The Sargasso Sea Stn 13.5 was sampled repeatedly during diel studies conducted on April 9 and 10, 2008; the other 8 stations were sampled only once. In the Mediterranean Sea and North Atlantic Ocean, samples were collected with General Oceanics 121 Niskin bottles mounted on a rosette equipped with a SeaBird SBE911+ (SBE19 at the bay station) conductivity-temperature-depth (CTD) instrument. The coastal lagoon Lapalme was sampled on April 13 and May 1, 2007. Here, the samples were collected using acid-washed Nalgene PC bottles rinsed 3 times with sampled water.

Fluorometry and particle size distributions. Bchl $a$ fluorescence was measured with an infrared (IR) kinetic fluorometer (Photon Systems Instruments) as described previously (Koblížek et al. 2007). To separate chlorophyll $a$ (chl $a$ ) and Bchl a contribution in the IR fluorescence signal $(>850 \mathrm{~nm})$, the oxygenic phytoplankton was selectively blocked by adding $10^{-5} \mathrm{M}$ (final concentration) of 3-(3,4-dichlorophenyl)-1,1dimethylurea (Diuron; PESTANAL, Fluka), which specifically binds photosystem II, but does not affect the bacterial reaction centers. Then, only the variable part of the kinetic IR signal originating from bacterial reaction centers was determined (Koblížek et al. 2005). This approach avoids potential interferences from other fluorescing compounds (not exhibiting variable fluorescence) or from electrical drifts within the detection system (occuring at different time scale).

Table 1. Main sampling stations. Samples were collected in surface waters $(3 \mathrm{~m})$ at all stations, and every $20 \mathrm{~m}$ between 0 and $100 \mathrm{~m}$ at Stn MOLA. nd: no data

\begin{tabular}{|c|c|c|c|c|c|c|c|c|}
\hline Location & Position & Regime & $\begin{array}{l}\text { Depth } \\
\text { (m) }\end{array}$ & Sampling date & $\begin{array}{l}\text { Temp. } \\
\left({ }^{\circ} \mathrm{C}\right)\end{array}$ & $\begin{array}{l}\text { Salinity } \\
\text { (PSU) }\end{array}$ & $\begin{array}{l}\mathrm{Chl} \mathrm{a} \\
\left(\mathrm{ng} \mathrm{l}^{-1}\right)\end{array}$ & $\begin{array}{l}\mathrm{Bchl} \mathrm{a} \\
\left(\mathrm{ng} \mathrm{l}^{-1}\right)\end{array}$ \\
\hline $\begin{array}{l}\text { Sargasso Sea } \\
\text { Stn } 13.5\end{array}$ & Sargasso Sea & Open ocean & 4875 & 9-10 Apr 08 & 21.2 & nd & 50 & $\sim 1.5^{\mathrm{a}}$ \\
\hline \multicolumn{9}{|c|}{ Mediterranean Sea } \\
\hline Stn MOLA & $42^{\circ} 27^{\prime} \mathrm{N}, 3^{\circ} 32^{\prime} \mathrm{E}$ & Offshore & 600 & $\begin{array}{l}10 \text { Apr } 07 \\
23 \text { May } 07\end{array}$ & $\begin{array}{l}14.4 \\
18.0\end{array}$ & $\begin{array}{l}38.1 \\
37.6\end{array}$ & $\begin{array}{l}590 \\
223\end{array}$ & $\begin{array}{l}0.9 \\
1.8\end{array}$ \\
\hline Stn POLA & $42^{\circ} 28^{\prime} \mathrm{N}, 3^{\circ} 15^{\prime} \mathrm{E}$ & Shelf & 90 & 21 May 07 & 18.6 & 37.8 & nd & $\sim 4^{\mathrm{a}}$ \\
\hline Stn SOLA & $42^{\circ} 29^{\prime} \mathrm{N} 3^{\circ} 08^{\prime} \mathrm{E}$ & Coastal bay & 27 & 9 May 07 & 16.5 & 36.6 & 318 & 3.9 \\
\hline Lapalme lagoon & $42^{\circ} 58^{\prime} \mathrm{N} 3^{\circ} 00^{\prime} \mathrm{E}$ & Coastal lagoon & 1.2 & 13 Apr 07 & 11.0 & 28.0 & 800 & 22 \\
\hline
\end{tabular}


Particle size distributions were measured with the Multisizer 3 Coulter Counter (Beckmen Coulter). Only particles with equivalent spherical diameters of $6 \mu \mathrm{m}$ and greater were considered and quantified using the total cumulative volume.

AAP bacteria enumeration. AAP bacteria were enumerated using previously described methods (Mašín et al. 2006). Briefly, bacterial cells were fixed using $2 \%$ paraformaldehyde (final concentration) and stored at $4^{\circ} \mathrm{C}$. Later, the samples were collected onto $0.2 \mu \mathrm{m}$ polycarbonate filters, dried, and stained with DAPI using a 3:1 mixture of Citifluor AF1 and Vectashield containing $1 \mu \mathrm{g} \mathrm{ml}^{-1}$ DAPI. First, the total DAPI-stained bacteria were recorded in the blue part of the spectrum (100 to $200 \mathrm{~ms}$ exposure). Then, IR emission (>850 nm) images were captured, showing both AAP bacteria and phytoplankton (from 15 to 35 s exposure). Finally, red chl a autofluorescence was recorded to identify chl a-containing organisms ( 0.5 to $1 \mathrm{~s}$ exposure). The acquired images were saved and semi-manually analyzed with the aid of AnalySiS software (Soft Imaging Systems) to distinguish between heterotrophic bacteria, picocyanobacteria and AAP bacteria for each sample. To obtain net AAP bacteria counts, the contribution of chl a-containing organisms to the IR image was subtracted (Schwalbach \& Fuhrman 2005). For each individual sample, 8 to 12 fields of view were recorded and analyzed (total count of 400 to 600 DAPI cells sample ${ }^{-1}$ ).

Pigment concentrations. Pigment concentrations were determined using HPLC, following previously published protocols (Ras et al. 2008). Between 1 and 51 seawater (depending on the trophic conditions) were filtered under low vacuum (<500 mbar) onto 2 stacked $25 \mathrm{~mm}$ GF/F filters which were frozen immediately at $-80^{\circ} \mathrm{C}$ until analysis. The samples were extracted in $3 \mathrm{ml}$ methanol (100\%) for a minimum of $1 \mathrm{~h}$, and sonicated. The clarified extracts were injected onto an Agilent Technologies 1100 series HPLC system equipped with a refrigerated autosampler and a column thermostat, according to a modified version of the method described by Ras et al. (2008). The sample extracts (100\% methanol), premixed (1:1) with a buffer solution (28 mM tetrabutylammonium acetate), were injected onto a narrow reversed-phase C8 Zorbax Eclipse XDB column $(3 \times 150 \mathrm{~mm} ; 3.5 \mu \mathrm{m}$ particle size $)$ which was heated to $60^{\circ} \mathrm{C}$. Separation was achieved within $28 \mathrm{~min}$ with a gradient between a solution (A) of $28 \mathrm{mM}$ tetrabutylammonium acetate: methanol (30:70; vol:vol) and a solution (B) of $100 \%$ methanol according to the following program: $0 \mathrm{~min}: 90 \% \mathrm{~A}, 10 \% \mathrm{~B} ; 25 \mathrm{~min}: 5 \% \mathrm{~A}$, $95 \%$ B; 28 min: $5 \%$ A, $95 \%$ B. The chromatogram was recorded by the on-line diode array detector. Carotenoids were recorded at $450 \mathrm{~nm}$, while chl $\mathrm{a}$ and its derivatives were detected at $667 \mathrm{~nm}$ and Bchl $a$ at
$770 \mathrm{~nm}$. The retention times and diode array absorption spectra of each peak were used for identification purposes. Pigment concentrations were calculated from the peak areas with an internal standard correction (Vitamin E acetate, Sigma) and external calibration standards which were provided by DHI Water and Environment and Sigma. This method has proven to be satisfactory in terms of resolution, sensitivity, accuracy and precision, with the detection of about 25 separate phytoplankton pigments (Ras et al. 2008), and a lower limit of detection (3 times signal:noise ratio) for chl a and Bchl $a$ of $0.1 \mathrm{ng} \mathrm{l}^{-1}$. The injection precision was $0.4 \%$.

\section{RESULTS}

The objective of the present work was to examine free-living and particle-attached AAP bacteria in 5 contrasting marine environments: a Mediterranean coastal lagoon, Mediterranean coastal and offshore waters, North Atlantic Ocean (including the Gulf Stream) and the Sargasso Sea. AAP bacterial cells were frequently seen attached to particles in samples collected from coastal waters by IR microscopy: the individual AAP bacterial cells were typically attached together with other bacteria to irregular particles of organic matter as shown in Fig. 1. Monospecific aggregates of AAP bacterial cells or phytoplankton cells selectively colonized by AAP bacterial cells were extremely rare (data not shown). Unfortunately, direct microscopic observations are labor-intensive and proper quantification of particle-attached cells is extremely complicated. For this reason Bchl a fluorescence was used in this study as an easy and rapid way to detect AAP bacteria (Kolber et al. 2000, 2001, Koblížek et al. 2005, 2007).

\section{Evaluation of the filtration methods}

Size fractionations were conducted to determine the percentage of total Bchl a fluorescence associated with particles. For each sample, $<0.8 \mu \mathrm{m}$ and $<2 \mu \mathrm{m}$ Bchl $a$ fluorescence signals were recorded with the original non-filtered water sample and the collected fractions, and the percentage of Bchl a signal in individual fractions was then calculated. Gravity filtration was used to minimize potential particle dislodging during the filtration processes (Ghiglione et al. 2007, Waidner \& Kirchman 2007).

In preliminary experiments we found that as expected a $0.2 \mu \mathrm{m}$ filtration always removed all the Bchl a signal. In a preliminary evaluation of our methods conducted at Stn POLA, we found that the majority $(67 \%)$ of the fluorescence signal was in the 0.4 to 

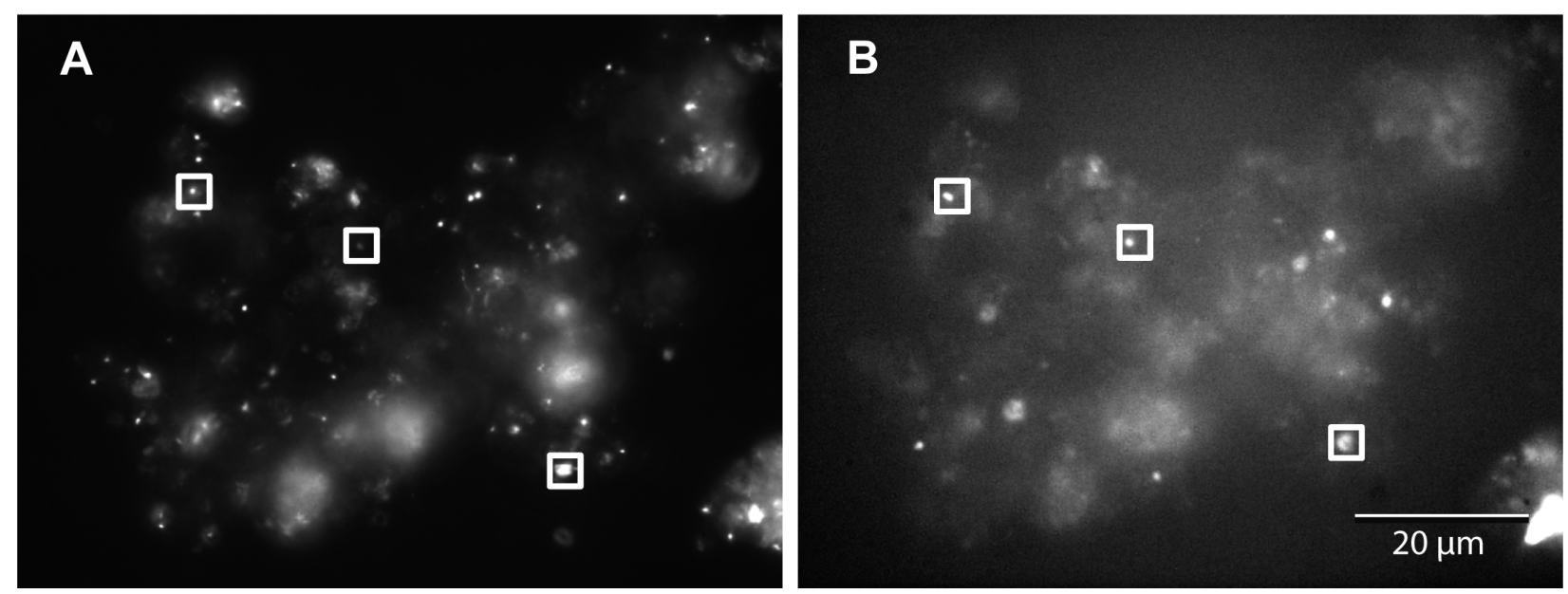

Fig. 1. (A) Particle-attached bacteria stained with DAPI and (B) infrared emission (>850 nm) of the sample. The squares indicate 3 aerobic anoxygenic phototrophic bacteria attached to a particle

$0.8 \mu \mathrm{m}$ fraction, with no signal below $0.4 \mu \mathrm{m}$ (Fig. 2). Only small part of the total signal was found in the larger size classes (13\% in 0.8 to $2.0 \mu \mathrm{m}$ fraction, $7 \%$ in 2 to $5 \mu \mathrm{m}$ and $12 \%$ in $>5 \mu \mathrm{m}$ fraction), which indicates that the majority of the AAP bacterial population was formed by small individual cells sized 0.4 to $0.8 \mu \mathrm{m}$ (Fig. 2).

The disadvantage of this size-fractionation protocol was lengthy filtration leading to slow deterioration of the samples. To avoid potential artifacts, the procedure was simplified to a 2-step protocol separating only 3 size classes: small cells passing through $0.8 \mu \mathrm{m}$ membrane filters, larger cells between 0.8 and $2 \mu \mathrm{m}$, and mostly particle-attached cells which do not pass through $2 \mu \mathrm{m}$ membrane filters. Using this protocol, the standard error of triplicate determinations on the same sample was $2.8 \%$. As the experimental error was

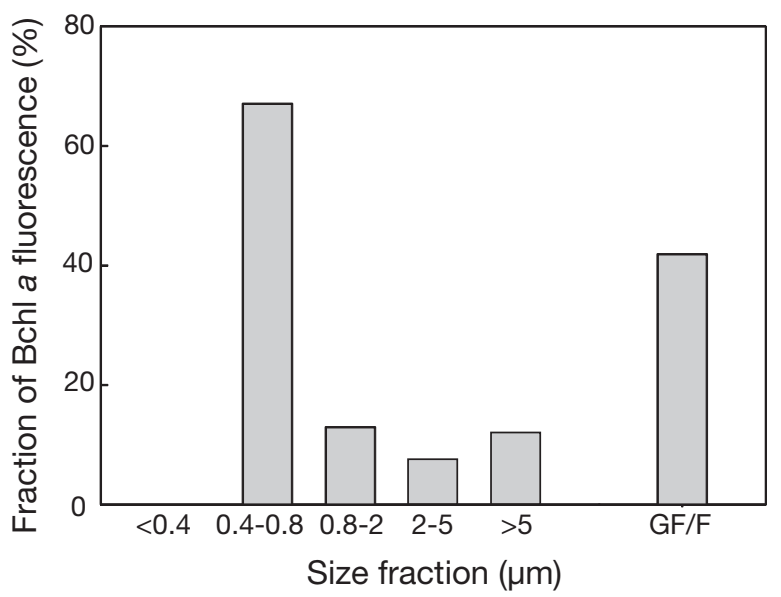

Fig. 2. Size fractionation of Bchl a fluorescence signal conducted at Stn POLA at $3 \mathrm{~m}$ depth on April 16, 2007. GF/F fraction indicates the percentage of the signal trapped by the GF/F filter during gravity filtration small, in later experiments the samples were analyzed only once to speed up the fractionation protocol.

Collection of water samples onto GF/F filters is a very common approach in marine microbiology. For this reason, we decided to test (in addition to nucleopore filtration) the ability of GF/F filters to retain the Bchl a fluorescence signal. The water samples collected at the coastal Stn SOLA in March and April 2007 were filtered through GF/F filters without vacuum. The filters retained $70 \%$ (in March) or $85 \%$ (April) of the Bchl a signal, which equals 15 to $30 \%$ of the signal passing through the filter. At Stn POLA, GF/F retained only $42 \%$ of the Bchl a signal (Fig. 2). The more dense MN GF-5 fiber glass filters (Macherey-Nagel) retained a larger fraction of the signal, but even these filters missed up to $30 \%$ of the Bchl a signal in the oligotrophic regions (data not shown).

\section{Mediterranean waters}

The size distribution of the Bchl a fluorescence signal was examined through March to May 2007 at the coastal bay Stn SOLA (Fig. 3). During this period, Bchl a concentrations increased from $1.5 \mathrm{ng} \mathrm{l}^{-1}$ in March to $3.5 \mathrm{ng} \mathrm{l}^{-1}$ in May. The $<0.8 \mu \mathrm{m}$ fraction (tracing free-living AAP bacteria) was the largest one (50 to $55 \%$, except April 16 to 23, during which it was 25 to $30 \%$ ). The $>2 \mu \mathrm{m}$ fraction (tracing particle-attached AAP bacteria) ranged from 20 to $40 \%$, while the 0.8 to $2 \mu \mathrm{m}$ fraction varied between 10 and $40 \%$ (Fig. 3).

The spatial changes in the AAP bacterial size distribution were examined at 3 time-series stations in offshore waters of Banyuls-sur-Mer in April and May 2007 (Table 1). At these studied Mediterranean sites, the AAP bacterial abundance in surface waters (deter- 


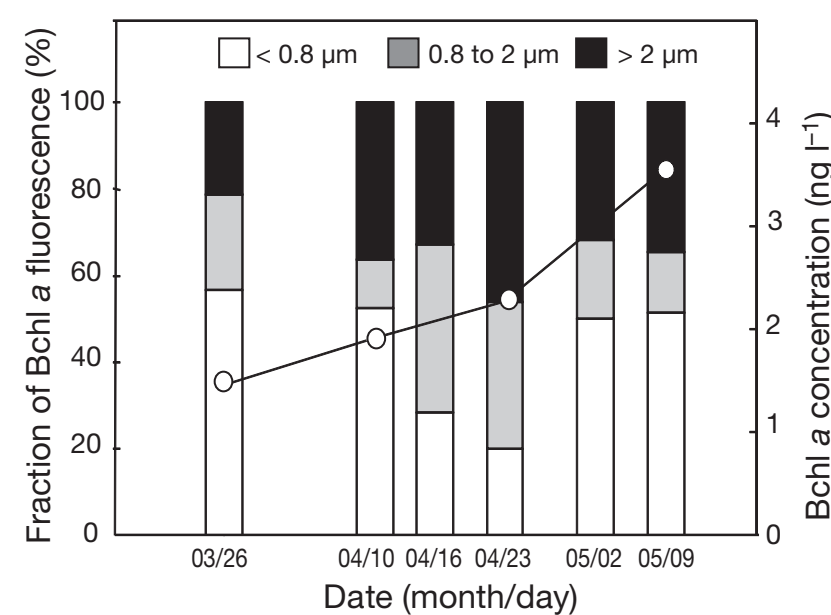

Fig. 3. Temporal variation of size fractionation of Bchl a fluorescence (bars) and variations of Bchl a concentrations (-O-) in the coastal Bay of Banyuls-sur-Mer, France, in spring 2007

mined with IR epifluorescence microscopy) ranged from $4.4 \times 10^{3}$ to $65 \times 10^{3}$ cells $\mathrm{ml}^{-1}$. Bchl a concentration measured by HPLC varied from 0.9 to $4.3 \mathrm{ng} \mathrm{l}^{-1}$, and the Bchl a:chl a ratio was between 0.6 and $1 \%$. At all these sites, the fraction of fluorescence in the $<0.8 \mu \mathrm{m}$ size fraction dominated the signal; however, its proportion varied. The highest fraction of the $<0.8 \mu \mathrm{m}$ signal was observed at the offshore Stn MOLA (up to $74 \%$ of the total signal in April), whereas at the shelf Stn POLA and the coastal site SOLA this fraction was smaller (55 to $65 \%$ of the total signal respectively) (Fig. 4). The 0.8 to $2 \mu \mathrm{m}$ fraction was present in all samples and was 10 to $40 \%$ of the total signal depending on the station and sample. The opposite pattern was found for the large fraction $(>2 \mu \mathrm{m})$, which mostly traces particle-attached AAP bacteria. Whereas at the offshore and shelf stations, this $>2 \mu \mathrm{m}$ fraction was about $10 \%$ of the total signal, it accounted for about $30 \%$ of the total Bchl a fluoresence signal at the coastal site (Fig. 4).

The vertical size distribution of the Bchl a signal was also examined at the offshore Stn MOLA on May 23, 2007 (Fig. 5). Here, Bchl a fluorescence in the $<0.8 \mu \mathrm{m}$ fraction was high at all depths and was relatively constant (40 to $50 \%$ of the total Bchl a signal) (Fig. 5). A large fraction ( $50 \%$ ) of the signal was recorded in the $>2 \mu \mathrm{m}$ fraction at the deep chlorophyll maximum (DCM). Interestingly, this pattern followed particulate matter volume determined using a Coulter counter. Particles and Bchl a concentrations measured by HPLC peaked at the DCM (up to $4.3 \mathrm{ng}^{-1}$ of Bchl $a$ and $70 \times$ $10^{3} \mu^{3} \mathrm{ml}^{-1}$ of particles at the DCM). AAP bacterial cell abundances varied from $6.6 \times 10^{3}$ to $34 \times 10^{3}$ cells $\mathrm{ml}^{-1}$ and peaked at $60 \mathrm{~m}$, just below the DCM (Fig. 5).

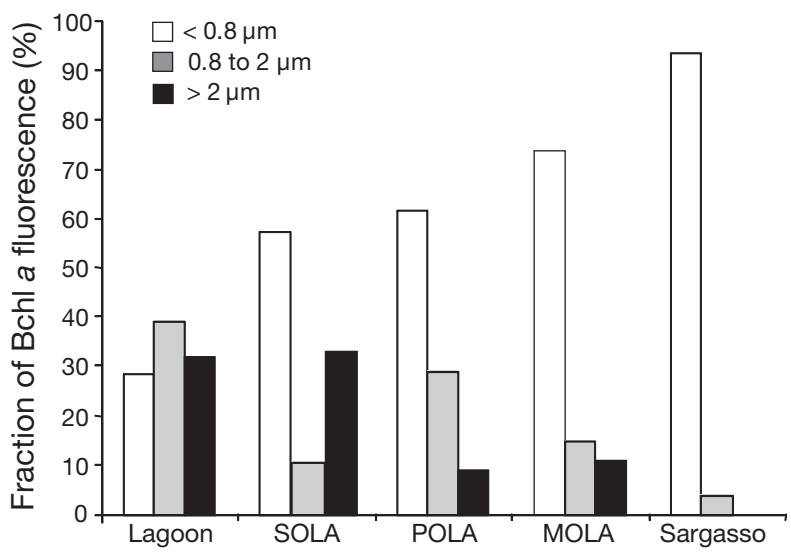

Fig. 4. Size fractionation of Bchl a fluorescence in a coastal Mediterranean lagoon, in Mediterranean coastal (bay, Stn SOLA; shelf, Stn POLA) and offshore (Stn MOLA) waters (spring 2007), and in the Sargasso Sea (April 2008)

We analyzed samples from a coastal Mediterranean lagoon (Lapalme Lagoon, France, 28 PSU) as a representative of an environment with high concentrations of particles. This shallow lagoon is characterized by high turbidity, and high chl a $\left(0.8 \mu \mathrm{g} \mathrm{l}^{-1}\right)$ and Bchl a (22 $\mathrm{ng} \mathrm{l}^{-1}$ ) concentrations (Table 1). In this lagoon, the percentage of total Bchl a fluorescence in the $<0.8 \mu \mathrm{m}$ fraction was $28 \%$. The signal in the $>2 \mu \mathrm{m}$ fraction reached $30 \%$ (Fig. 4).

\section{North Atlantic Ocean}

We performed size-fractionation experiments in the northwest Atlantic in April 2008. In the Sargasso Sea, the Gulf Stream and in northern Atlantic waters, concentrations of Bchl a were between 0.8 and $1.6 \mathrm{ng} \mathrm{l}^{-1}$. In the oligotrophic Sargasso Sea, $90 \pm 2 \%$ (mean $\pm \mathrm{SE}$ ) of Bchl a passed through the $0.8 \mu \mathrm{m}$ filter (calculated from 6 independent casts at Stn 13.5) and all Bchl a passed through the $2 \mu \mathrm{m}$ filter (Fig. 6). In addition, $0.4 \mu \mathrm{m}$ filtration usually removed $>90 \%$ of the Bchl $a$ signal, which indicates that in the Sargasso Sea the majority of AAP bacterial cells were between 0.4 and $0.8 \mu \mathrm{m}$ in size, and particle-attached AAP bacteria were absent. The size-fractionation measurements were also performed along the transect from the Sargasso Sea (Stn $16,33^{\circ} \mathrm{N} 65^{\circ} \mathrm{W}$ ) to the coast (Woods Hole, MA). In 3 samples collected in the Sargasso Sea, the $<0.8 \mu \mathrm{m}$ fraction varied between 86 and $98 \%$ of the total, and $>2 \mu \mathrm{m}$ fraction was absent. In the Gulf Stream $\left(38^{\circ} \mathrm{N}, 69.5^{\circ} \mathrm{W}\right)$ the $<0.8 \mu \mathrm{m}$ fraction decreased to $77 \%$, whereas the $>2 \mu \mathrm{m}$ fraction was $9 \%$ of the total Bchl a signal. In the productive waters of the Mid- 


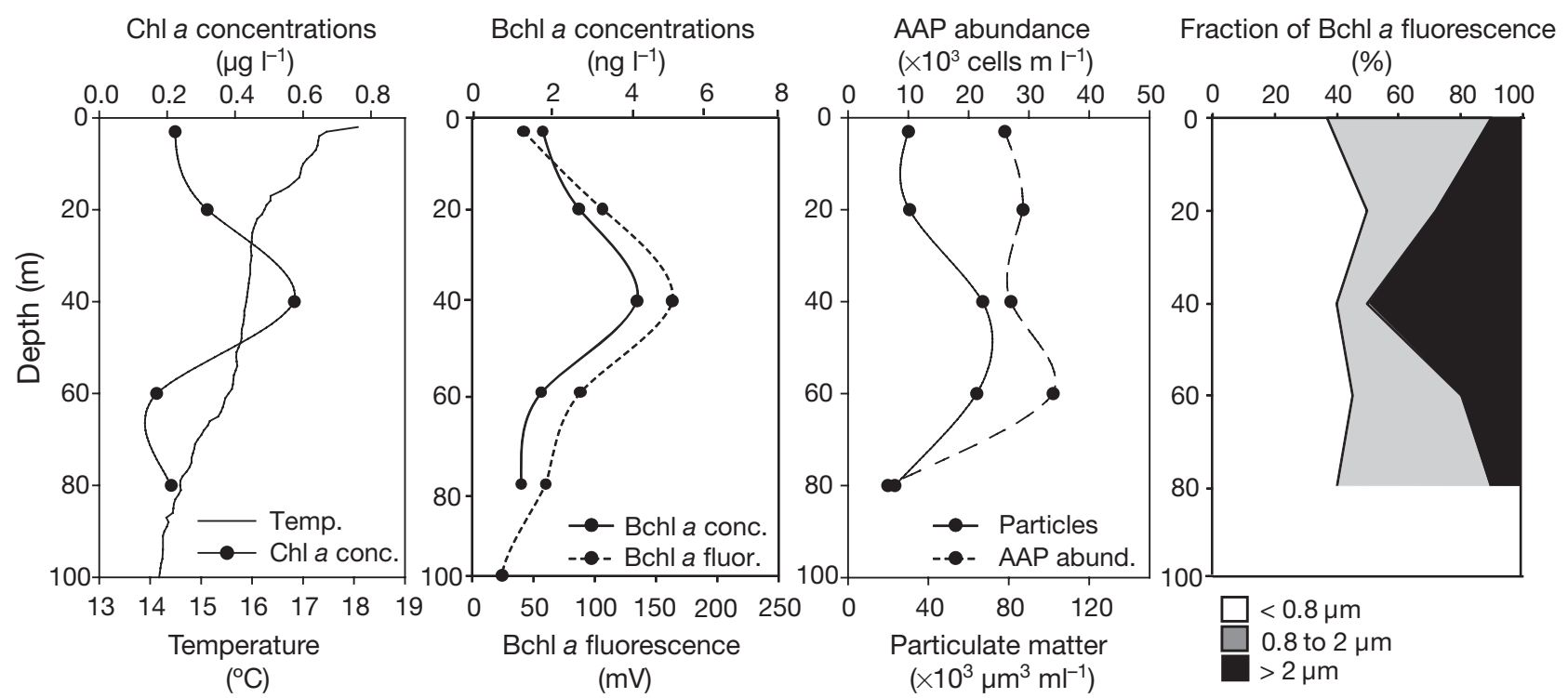

Fig. 5. Vertical distribution of temperature (temp.) and chlorophyll a concentrations (chl a), Bchl a concentrations (conc.), and Bchl a fluorescence (fluor.), aerobic anoxygenic phototrophic bacterial abundance (AAP abundance) and particulate matter, and size fractionation of Bchl a fluorescence with depth. Data collected in Mediterranean offshore waters (Stn MOLA; May 23, 2007)

dle Atlantic Bight, the small fraction further decreased to 50 to $68 \%$, while the large $>2 \mu \mathrm{m}$ fraction increased to 22 to $30 \%$ of the total Bchl a signal (Fig. 6).

\section{DISCUSSION}

We investigated the distribution of particle-attached and free-living AAP bacteria by the detection of Bchl a fluorescence after size fractionation of seawater in var- ious oceanographic contexts. Data on free-living versus particle-attached AAP bacterial populations in marine waters are scarce. In their pioneering paper, Kolber et al. (2000) reported that most AAP bacteria in the subtropical Pacific pass through the GF/F filter, which suggests that the community is composed mostly of single cells $<0.7 \mu \mathrm{m}$. In contrast, large quantities of particle-attached AAP bacteria (31 to $94 \%$ ) in estuarine waters were reported by Waidner \& Kirchman (2007). Our data clearly show that the proportion
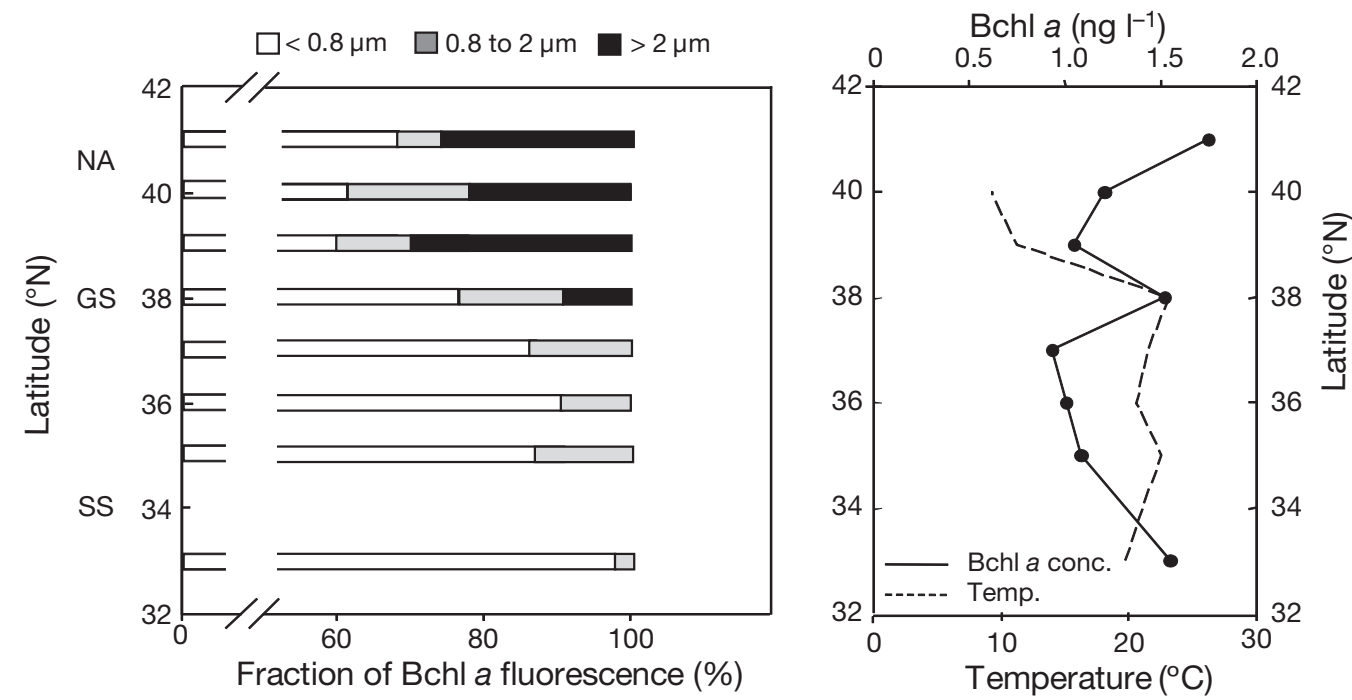

Fig. 6. Size fractionation of Bchl a fluorescence in the North Atlantic (NA) and Sargasso Sea (SS). Samples were taken during the transect from SS (Stn $16,33^{\circ} \mathrm{N}, 66^{\circ} \mathrm{W}$ ) to Woods Hole, MA $\left(41^{\circ} 31.4^{\prime} \mathrm{N}, 70^{\circ} 40.3^{\prime} \mathrm{W}\right)$ on April 10 to 13,2008 . The Gulf Stream (GS) was crossed at $38^{\circ} \mathrm{N}$. The right-hand panel shows temperatures and Bchl a concentrations (estimated from Bchl a fluorescence) measured along the transect 
of free-living and particle-attached AAP bacteria varies among the environments. In offshore and openocean environments, the majority of the AAP bacterial community were small $(<0.8 \mu \mathrm{m})$ free-living cells, which agrees with the findings of Kolber et al. (2000). Interestingly, our estimate of size ranges for the Sargasso Sea community $(0.4$ to $0.8 \mu \mathrm{m})$ agrees with AAP bacterial cell sizes (0.4 to $1.0 \mu \mathrm{m})$ determined by Sieracki et al. (2006) in the same region using epifluorescence microscopy. Our observations are in contrast with metagenomic analyses conducted in the oligotrophic Sargasso Sea suggesting that the majority of AAP bacteria are in the 3 to $20 \mu \mathrm{m}$ fraction (Yutin et al. 2007).

We found a measurable percentage of Bchl a fluorescence in the 0.8 to $2 \mu \mathrm{m}$ fraction in all environments. This signal likely comes from large but free-living AAP bacteria. It has previously been shown both in the North Atlantic and South Pacific Oceans that these microorganisms are larger than average heterotrophic bacterioplankton cells (Sieracki et al. 2006, Lami et al. 2007). It has been suggested that large cells may be the most active members of the bacterioplankton community (Bird \& Kalff 1993, Gasol et al. 1995).

A different pattern was observed in a coastal lagoon and bay, where up to one-third of the AAP bacterial community was particle-attached. This is consistent with the large fraction of particle-attached AAP bacteria reported by Waidner \& Kirchman (2007) from Chesapeake and Delaware estuaries. Interestingly, this pattern follows the usual observations of particleattached versus free-living prokaryotes in the sea, with the highest percentages of attached bacteria in environments with high concentrations of particles (Simon et al. 2002). Collectively, the data presented in the present study show that AAP bacteria, in comparison with regular heterotrophic prokaryotes, do not exhibit an enhanced tendency to attach to particles or to form clumps. However, as the AAP bacterial community is composed of phylogenetically diverse organisms (Yutin et al. 2007, Salka et al. 2008), some AAP bacterial species might have an enhanced tendency to attach to particles as a part of their lifestyle.

We observed high AAP bacterial abundances at the DCM, consistent with high Bchl a concentrations. This was previously found in other marine environments (Kolber et al. 2000, 2001, Sieracki et al. 2006). The slight decoupling between the peak of AAP bacterial cells and the peak of Bchl a may be due to regulation of Bchl a content per cell. The interpretation of this peak of photoheterotrophs is not completely clear. On the one hand, AAP bacteria and phytoplankton may require the same environmental conditions (light and nutrients) for their growth. Thus, they may occupy similar ecological niches and might strongly compete for similar resources. On the other hand, AAP bacteria may find at the DCM specific organic compounds provided by phytoplankton and required for their growth. Interestingly, we recorded a large fraction of AAP bacteria attached to particles at the DCM, twice as much as in surface and deep layers. Attachment of AAP bacterial populations also follows closely the distribution of particles in the water column as well as chl a concentrations. Thus, their attachment to particles probably also depends on the concentrations of particles, including phytoplankton. The attached AAP bacteria may use a large spectrum of molecules, including diverse dissolved organic matter provided by various algal groups.

For pigment analyses, planktonic samples are routinely collected onto glass fiber GF/F filters (Whatman). Kolber et al. (2000) reported that in the tropical Pacific most of the Bchl a signal passes through GF/F. In contrast, Goericke (2002) reported high retention of Bchl $a$ on GF/F filters in his HPLC analyses. Based on our data, it seems that the use of GF/F filters for pigment analyses in open-ocean environments might lead to a significant underestimation of true Bchl a concentrations, as GF/F filters did not trap 30 to $60 \%$ of the total Bchl a signal in our experiments. This is consistent with earlier observations from the subtropical Atlantic, where 50 to $65 \%$ of the signal passed through GF/F filters (M. Koblížek unpubl. data). The GF/F filtration conducted at coastal Stn SOLA seemed to be more effective. However, in a previous study conducted in the Bay of Villfranche, France, the GF/F filters did not trap 30 to $50 \%$ of the signal (Koblížek et al. 2007).

The environmental variables that control AAP bacterial abundance and dynamics remain a matter of debate. Our data suggest that the characterization of 'free-living' versus 'particle-attached' is an important factor to explain the distribution and the ecology of AAP bacteria in marine environments. We have shown that AAP bacteria are mainly free living in the oceans. In addition, our data strongly suggest that in coastal bays and lagoons, large fractions of AAP bacterial cells have a particle-attached lifestyle. It has been shown that particle-attached bacteria can be the most active members of the prokaryotic community (Grossart et al. 2007). Thus, in coastal environments (lagoon, shelf) and at the DCM, some AAP bacteria may play significant roles in the mineralization of organic matter and particulate detritus degradation.

Acknowledgements. We thank L. Oriol, J. Caparros and I. Obernosterer for the Mediterranean sample collection at Stn MOLA during the project MEDEA (INSU-LEFE-CYBER, P.I., I. Obernosterer), L. Zudaire for the CTD data and the captain and the crew of the RV 'Nereis' and RV 'Tethys II' for their support. The authors also thank the chief scientist B. Van Mooy for organizing the OC443 cruise and the captain and 
the crew of RV 'Oceanus' for their performance at sea. We thank J. J. Naudin at the Service d'Observation du Laboratoire Arago for oceanographic data and the French monitoring network SOMLIT for oceanographic coastal data. R.L.'s research was supported by a doctoral fellowship from the French Research and Education Ministry and by the Lavoisier postdoctoral fellowship from the French Foreign Office. M.K.'s stay in Banyuls was supported by a fellowship from the Université Pierre et Marie Curie - Paris 6. This research was also supported by GACR project 206/07/0241, GAAV project 1QS500200570 and the Inst. research concepts MSM6007665808 and AV0Z50200510. We are grateful to D. L. Kirchman and his group in the College of Marine and Earth Studies for helpful comments on an earlier version of this manuscript.

\section{LITERATURE CITED}

Allgaier M, Uphoff H, Felske A, Wagner-Döbler I (2003) Aerobic anoxygenic photosynthesis in Roseobacter clade bacteria from diverse marine habitats. Appl Environ Microbiol 69:5051-5059

Béjà O, Aravind L, Koonin EV, Suzuki MT and others (2000) Bacterial rhodopsin: evidence for a new type of phototrophy in the sea. Science 289:1902-1906

Bird DF, Kalff J (1993) Protozoan grazing and size-activity structure of limnetic bacterial communities. Can J Fish Aquat Sci 50:370-380

Cottrell MT, Mannino A, Kirchman DL (2006) Aerobic anoxygenic phototrophic bacteria in the Mid-Atlantic Bight and the North Pacific Gyre. Appl Environ Microbiol 72: 557-564

Gasol JM, del Giorgio PA, Massana R, Duarte CM (1995) Active versus inactive bacteria: size-dependence in a coastal marine plankton community. Mar Ecol Prog Ser 128:91-97

Ghiglione JF, Mevel G, Pujo-Pay M, Mousseau L, Lebaron P, Goutx M (2007) Diel and seasonal variations in abundance, activity and community structure of particleattached and free-living bacteria in NW Mediterranean Sea. Microb Ecol 54:217-231

Goericke R (2002) Bacteriochlorophyll $a$ in the ocean: Is anoxygenic bacterial photosynthesis important? Limnol Oceanogr 47:290-295

Grossart HP, Tang KW, Kiøboe T, Ploug H (2007) Comparison of cell-specific activity between free-living and attached bacteria using isolates and natural assemblages. FEMS Microbiol Lett 266:194-200

Jiao N, Zhang Y, Zeng Y, Hong N, Liu R, Chen F, Wang P (2007) Distinct distribution pattern of abundance and diversity of aerobic anoxygenic phototrophic bacteria in the global ocean. Environ Microbiol 9:3091-3099

Koblížek M, Ston-Egiert J, Sagan S, Kolber ZS (2005) Diel changes in bacteriochlorophyll a concentration suggest rapid bacterioplankton cycling in the Baltic Sea. FEMS Microbiol Ecol 51:353-361
Koblížek M, Mašín M, Ras J, Poulton AJ, Prášil O (2007) Rapid growth rates of aerobic anoxygenic phototrophs in the ocean. Environ Microbiol 9:2401-2406

- Kolber ZS, Van Dover CL, Niederman RA, Falkowski PG (2000) Bacterial photosynthesis in surface waters of the open ocean. Nature 407:177-179

- Kolber ZS, Plumley FG, Lang AS, Beatty JT and others (2001) Contribution of aerobic photoheterotrophic bacteria to the carbon cycle in the ocean. Science 292:2492-2495

Lami R, Cottrell MT, Ras J, Ulloa O, Obernosterer I, Claustre H, Lebaron P (2007) High abundances of aerobic anoxygenic photosynthetic bacteria in the South Pacific Ocean. Appl Environ Microbiol 73:4198-4205

Mašín M, Zdun A, Stoń-Egiert J, Nausch M, Labrenz M, Moulisová V, Koblížek M (2006) Seasonal changes and diversity of aerobic anoxygenic phototrophs in the Baltic Sea. Aquat Microb Ecol 45:247-254

> Mašín M, Nedoma J, Pechar L, Koblížek M (2008) Distribution of aerobic anoxygenic phototrophs in temperate freshwater systems. Environ Microbiol 10:1988-1996

Ras J, Claustre H, Uitz J (2008) Spatial variability of phytoplankton pigment distributions in the subtropical South Pacific Ocean: comparison between in situ and predicted data. Biogeosciences 5:353-369

Salka I, Moulisová V, Koblížek M, Jost G, Jürgens K, Labrenz M (2008) Abundance, depth distribution, and composition of aerobic bacteriochlorophyll a-producing bacteria in four basins of the central Baltic Sea. Appl Environ Microbiol 74:4398-4404

Schwalbach MS, Fuhrman JA (2005) Wide-ranging abundances of aerobic anoxygenic phototrophic bacteria in the world ocean revealed by epifluorescence microscopy and quantitative PCR. Limnol Oceanogr 50:620-628

Sieracki ME, Gilg IC, Thier EC, Poulton NJ, Goericke R (2006) Distribution of planktonic aerobic anoxygenic photoheterotrophic bacteria in the Northwest Atlantic. Limnol Oceanogr 51:38-46

> Simon M, Grossart HP, Schweitzer B, Ploug H (2002) Microbial ecology of organic aggregates in aquatic ecosystems. Aquat Microb Ecol 28:175-211

> Waidner LA, Kirchman DL (2007) Aerobic anoxygenic phototrophic bacteria attached to particles in turbid waters of the Delaware and Chesapeake estuaries. Appl Environ Microbiol 73:3936-3944

> Yurkov VV, Beatty JT (1998) Aerobic anoxygenic phototrophic bacteria. Microbiol Mol Biol Rev 62:695-724

> Yutin N, Suzuki MT, Teeling H, Weber M, Venter JC, Rusch DB, Béjà O (2007) Assessing diversity and biogeography of aerobic anoxygenic phototrophic bacteria in surface waters of the Atlantic and Pacific Oceans using the Global Ocean Sampling expedition metagenomes. Environ Microbiol 9:1464-1475

Zubkov MV, Tarran GA (2005) Amino acid uptake of Prochlorococcus spp. in surface waters across the South Atlantic Subtropical Front. Aquat Microb Ecol 40:241-249

Submitted: July 1, 2008; Accepted: January 15, 2009

Proofs received from author(s): March 8, 2009
Editorial responsibility: Jed Fuhrman,

Los Angeles, California, USA 